\title{
Mengenal pentingnya perawatan diri (self care) bagi konselor dalam menghadapi stres
}

\author{
Dinny Rahmayanty ${ }^{1^{*}}$, Eka Wahyuni ${ }^{2}$, \& Lara Fridani ${ }^{3}$ \\ Universitas Negeri Jakarta ${ }^{123}$ \\ *) Alamat korespondensi: Jl. R. Mangun Muka Raya No. 11, Jakarta Timur, 13220, Indonesia; E-mail: \\ dinnyrahmayanty_bk16s2@mahasiswa.unj.ac.id
}

\section{Article History \\ Received: 26/06/2021; \\ Revised: 27/06/2021; \\ Accepted: $27 / 06 / 2021$}

Published: 30/06/2021.

How to cite:

Rahmayanty, D, Wahyuni, E., \& Fridani, L. (2021). Mengenal pentingnya perawatan diri (self care) bagi konselor dalam

menghadapi stres. Teraputik:

Jurnal Bimbingan dan Konseling, 5(1), pp. 125-131. DOI: 10.26539/teraputik.51669

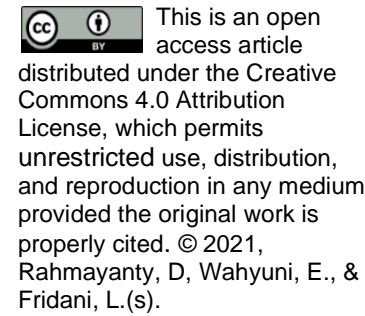

\begin{abstract}
Abstrak: Tujuan penulisan artikel ini untuk menyajikan pentingnya perawatan diri bagi konselor dalam menghadapi stres. Metodologi atau pendekatan yang digunakan dalam tulisan ini menggunakan metode atau pendekatan kepustakaan, sedangkan pengumpulan data dilakukan dengan menelaah dan/atau mengekplorasi beberapa jurnal, buku, serta sumber lain yang relevan dengan kajian. Temuan dalam kajian ini adalah mengenali pentingnya perawatan diri bagi konselor dalam menghadapi stres. Seorang konselor setidaknya mengetahui gejala stres yang dialaminya sehingga bisa menemukan panduan perawatan diri yang dirasa tepat untuk mengatasi stres yang dialami. Dengan teratasinya stres yang dialami oleh seorang konselor, diharapkan mereka dapat semaksimal mungkin menjalankan tugas dan tanggung jawabnya sebagai seorang konselor di sekolah.
\end{abstract}

Kata Kunci: Perawatan Diri, Selfcare, Stres, Konselor

Abstract: The purpose of writing this article is to present the importance of self-care for counselors in dealing with stress. The methodology or approach used in this paper uses a library method or approach, while data collection is carried out by reviewing and/or exploring several journals, books, and other sources relevant to the study. The findings in this study are to recognize the importance of self-care for counselors in dealing with stress. A counselor at least knows the symptoms of stress they are experiencing so they can find a self-care guide that they feel is appropriate to deal with the stress they are experiencing. By overcoming the stress experienced by a counselor, it is hoped that they can carry out their duties and responsibilities as a counselor at school as much as possible.

Keywords: Self Care, Selfcare, Stress, Counselor

\section{Pendahuluan}

Dalam Sistem Pendidikan Nasional, keberadaan konselor dinyatakan sebagai salah satu kualifikasi pendidik, sejajar dengan kualifikasi guru, dosen, pamong belajar, tutor, widyaiswara, fasilitator, dan instruktur (UU No. 20 Tahun 2003 Pasal 1 Ayat 6). Dalam Permendiknas Nomor 27 Tahun 2008, konteks tugas konselor berada dalam kawasan pelayanan yang bertujuan mengembangkan potensi dan memandirikan konseli (klien) dalam pengambilan keputusan dan pilihan untuk mewujudkan kehidupan yang produktif, sejahtera, dan peduli kemaslahatan umum $(111,2014)$.

Menurut Permendikbud No. 111 Tahun 2014, konselor merupakan profesi yang berperan besar dan mempunyai kedudukan penting dalam dunia pendidikan. Konselor memikul tanggung jawab besar karena dituntut untuk mencetak sumber daya manusia yang berkualitas. Konselor merupakan salah satu tenaga pendidik di sekolah yang mengemban amanah untuk menyusun rencana pelayanan bimbingan dan konseling, melaksanakan pelayanan bimbingan dan konseling, mengevaluasi proses dan hasil pelayanan bimbingan dan konseling serta melakukan perbaikan tindak lanjut dengan memanfaatkan hasil evaluasi yang telah dilakukan.

Dalam menjalankan tugas dan fungsinya di sekolah, konselor dituntut untuk memiliki kompetensi-kompetensi yang mendukung kinerja konselor tersebut agar dapat menjadi tenaga yang profesional serta ahli di bidangnya sehingga kedepannya akan menentukan kualitas konselor itu sendiri. Kualitas konselor meliputi semua kriteria keunggulan termasuk pribadi, 
pengetahuan, wawasan, keterampilan, dan nilai-nilai yang dimiliki konselor, yang akan menentukan keberhasilan (efektivitas) dalam proses bimbingan dan konseling (Fuad, 2009).

Hasil penelitian yang dilakukan oleh Wahyudi (2017) mengemukakan bahwa peran konselor di sekolah sangat banyak, terlebih untuk internal bimbingan dan konseling sendiri yaitu melayani enam kelas, yang setiap kelasnya ada sekitar 32 siswa. Apabila dijumlahkan, maka seorang konselor sekolah melayani sekitar 192 siswa. Hal ini tentunya bertentangan dengan Permendikbud RI No. 111 Tahun 2014 Pasal 10 Ayat (2) yang menyatakan bahwa "Penyelenggaraan Bimbingan dan Konseling pada SMP/MTs atau yang sederajat, SMA/MA atau yang sederajat, dan SMK/MK atau yang sederajat dilakukan oleh konselor atau guru Bimbingan dan Konseling dengan rasio satu konselor atau guru Bimbingan dan Konseling melayani 150 orang konseli atau peserta didik".

. Keberhasilan dalam memberikan layanan terhadap klien merupakan suatu kepuasan bagi seorang konselor, terlebih apabila konselor berhasil pula mengerjakan tugas gandanya diluar pelayanan dalam Bimbingan dan Konseling seperti menjadi pengelola beasiswa, menjadi wali kelas, dan koordinator keputrian. Konselor tidak selamanya berhasil dalam menjalankan tugasnya, ketidakberhasilan inilah yang terkadang akan menimbulkan stres.

Banyak konselor mengalami kelelahan, baik secara fisik maupun emosional. Konselor dihadapkan pada masalah-masalah emosi siswa, persoalan siswa ini sering melibatkan emosional konselor secara berlebihan. Konselor yang mengalami tekanan secara emosional bisa menyebabkan stres sehingga bisa merasakan energi yang terkuras habis atau kelelahan jika menangani masalah anak dalam kesehariannya. Ditambah lagi, konselor terkadang membawa permasalahan siswa ke dalam pikirannya sehingga mengalami kesulitan tidur.

Stres yang berlebihan akan berakibat buruk terhadap kemampuan individu untuk berhubungan dengan lingkungannya secara normal. Stres dapat dialami konselor sekolah karena stres merupakan masalah umum yang terjadi dalam kehidupan manusia dan sudah menjadi bagian hidup yang terkadang tidak bisa dihindari. Konselor rentan mengalami stres yang disebabkan oleh berbagai macam faktor, misalnya saja peran individu dalam organisasi, pengembangan karir, hubungan dalam pekerjaan, struktur dalam iklim organisasi, dan tuntutan dari luar pekerjaan (Sandra \& Ifdil, 2015).

Menurut Hartono dan Soedarmadji (2012) stres adalah suatu bentuk gangguan emosi yang disebabkan adanya tekanan yang tidak dapat diatasi oleh individu. tuntutan pekerjaan yang berat, serta kondisi lingkungan pekerjaan yang syarat dengan masalah bisa menjadikan persoalan tersendiri bagi konselor. Stres kerja atau beban kerja konselor yang diabaikan akan dapat berkembang menjadi depresi yang berpotensi menimbulkan munculnya berbagai penyakit fisik dan menurunkan produktivitas serta kualitas hidup seseorang.

Selama ini konselor menganggap permasalahan yang terjadi dalam dirinya akan terselesaikan dengan sendirinya, tidak sedikit pula yang mencoba menghindari penyebab stres yang mereka alami. Ketika hal ini dibiarkan maka dapat mengarah ke berbagai hasil negatif termasuk terganggunya kesehatan fisik dan mental dari konselor itu sendiri (Dorociak, et al, 2017). Sering kali konselor menemukan bahwa mereka mengabaikan perawatan diri (Bradley, et al, 2013) dan bersandar pada pepatah "konselor menyembuhkan dirinya sendiri". Perawatan diri atau self care ini dapat secara luas didefinisikan sebagai tindakan atau pengalaman yang meningkatkan atau mempertahankan kesejahteraan konselor, termasuk kegiatan seperti makan makanan yang seimbang dan bergizi, berolahraga, tidur yang cukup, dan mencari dukungan profesional lain.

Apabila seorang konselor mengalami stres dan tidak diselesaikan atau cenderung dihindari, hal tersebut akan berdampak pada kualitas pelayanan yang diberikan kepada siswa di sekolah. Hal ini didasarkan pada penelitian yang dilakukan oleh Komar (2011), dalam menjalankan tugasnya, tidak sedikit beban kerja yang harus diemban oleh seorang konselor sehingga mungkin akan menimbulkan stres dan mengalami kelelahan fisik, gangguan pernafasan, gangguan kulit, ketegangan otot, sakit kepala, dan gangguan tidur.

Penelitian lain yang dilakukan oleh Susanti, dkk (2018) mengenai apa yang dirasakan terkait kondisi tubuh dan emosi konselor di beberapa SMAN kota Pekanbaru, Kabupaten Kampar dan Kuansing rata-rata konselor sering merasakan sakit kepala, keletihan, merasa bosan dengan 
lingkungan sekolah, mudah marah dan tersinggung, merasa tidak puas dengan pekerjaan, mengalami tekanan dari kepala sekolah, siswa, dan wali murid.

Dalam penelitian tersebut juga disebutkan bahwa konselor sangat menyukai pekerjaan mereka, namun jika ada peluang lain atau pensiun, maka peluang tersebut akan diambil. Siswa sekarang sangat berbeda dengan siswa zaman dahulu. Saat ini banyak siswa yang berperilaku aneh, tidak teratur, sekolah sesukanya, dan tidak memiliki rasa hormat dengan guru. Konselor merasa sangat lelah karena tidak jarang masalah siswa tersebut terbawa sampai di rumah.

Berdasarkan uraian di atas, penting untuk mengetahui mengenai perawatan diri (self care) untuk membantu konselor dalam menghadapi stres. Hal ini mendorong peneliti untuk melakukan penelitian studi kepustakaan mengenai perawatan diri atau self care bagi konselor dalam menghadapi stres meliputi: 1) pengertian stres kerja, 2) pengertian perawatan diri, 3) aspekaspek perawatan diri, 4) manfaat perawatan diri bagi konselor, dan 5) bentuk strategi perawatan diri.

\section{Metode}

Penelitian ini menggunakan metode berupa studi kepustakaan (library research). Studi pustaka berkaitan dengan kajian teoritis dan beberapa referensi yang tidak akan lepas dari literatur-literatur ilmiah (Sugiyono, 2012). Ciri utama studi kepustakaan menurut Zed (2008, dalam Azizah \& Purwoko, 2017 ) meliputi: 1) Peneliti berhadapan langsung dengan teks atau data angka dan bukan pengetahuan langsung dari lapangan atau saksi mata berupa kejadian, orang, atau benda-benda lainnya; 2) Data pustaka bersifat siap pakai artinya peneliti tidak pergi kemana-mana kecuali berhadapan langsung dengan bahan sumber yang sudah tersedia di perpustakaan; 3) Data pustaka umumnya adalah sumber sekunder, artinya peneliti memperoleh bahan dari tangan kedua dan bukan data orisinil dari tangan pertama di lapangan; dan 4) Kondisi data pustaka tidak dibatasi oleh ruang dan waktu.

\section{Hasil dan Diskusi}

\section{Pengertian Stres Kerja}

Lazarus \& Folkman (1984, dalam Rumeser, dkk, 2011), stres terjadi saat terdapat ketidaksesuaian antara tuntutan lingkungan dan kemampuan seseorang yang kemudian akan melakukan penilaian terhadap lingkungannya, melebihi kemampuan yang dimilikinya atau bahkan mengancam kesejahteraannya. Sedangkan menurut Cox (1993, dalam Stranks, 2015), stres dipahami sebagai keadaan psikologis yang merupakan hasil dari persepsi orang terhadap ketidakseimbangan antara tuntutan pekerjaan dan kemampuan mereka untuk mengatasi tuntutan itu.

Menurut Stranks (2015), stres kerja adalah keadaan psikologis yang dapat menyebabkan individu untuk berperilaku disfungsi di tempat kerja dan hasil dari tanggapan orang terhadap ketidakseimbangan antara tuntutan pekerjaan dan kemampuan mereka untuk mengatasinya. Menurut Keenan \& Newton (dalam Wijono, 2011) stres kerja adalah perwujudan dari kekaburan peran, konflik peran, dan beban kerja yang berlebihan.

Berdasarkan pendapat beberapa ahli diatas, stres kerja merupakan keadaan psikologis yang dapat menyebabkan individu untuk berperilaku disfungsi di tempat kerja sehingga terjadi ketidakseimbangan antara tuntutan pekerjaan dan kemampuan mereka untuk mengatasi kekaburan peran, konflik peran, dan beban kerja yang berlebihan.

\section{Pengertian Perawatan Diri}

Menurut Norcross dan Guy (2207), praktisi kesehatan mental memiliki tugas etis untuk memberikan perawatan yang bertanggung jawab, memaksimalkan manfaat dan meminimalkan bahaya bagi klien mereka. Untuk memberikan perawatan yang efektif kepada klien mereka, para praktisi harus terlebih dahulu memastikan bahwa diri mereka baik-baik saja. Perawatan diri 
bukanlah suatu kemewahan, tetapi merupakan keharusan klinis dan etis dalam profesi kesehatan mental sehingga penting untuk memahami efektivitas dari berbagai bentuk perawatan diri.

Upaya proaktif yang sedang berlangsung untuk menghadapi stres dan mempromosikan kesehatan psikologis sangat penting dalam setiap karir psikolog, dan perawatan diri harus didorong sebagai aspek penting dalam kehidupan sehari-hari. Perawatan diri paling sering dilambangkan sebagai keterlibatan dalam suatu kegiatan tertentu untuk meningkatkan kesehatan, kesejahteraan, dan menghilangkan stres (Brucato \& Neimeyer, 2009; Jordan, 2010; Stebnicki, 2007, dalam Dorociak, 2015).

Dengan demikian, perawatan diri adalah upaya proaktif yang dilakukan dalam bentuk kegiatan yang merupakan keharusan klinis dan etis untuk meningkatkan kesehatan, kesejahteraan, dan menghilangkan stres.

\section{Aspek-aspek Perawatan Diri}

Baker ( 2003, dalam Dorociak, 2015 ) menyatakan bahwa perawatan diri terdiri dari 3 aspek antara lain: kesadaran diri akan pengalaman fisik dan psikologi seseorang; regulasi reaksi pribadi dan profesional seseorang; dan keseimbangan koneksi antara diri sendiri, orang lain, dan komunitas yang lebih besar. Carrol et al ( 1999, dalam Dorociak, 2015 ) mengklasifikasikan perilaku perawatan diri menjadi empat kategori yaitu: pekerjaan interpersonal, dukungan interpersonal, pengembangan dan dukungan profesional, dan kegiatan fisik/ rekreasi.

Lee \& Miller ( 2013, dalam Dorociak, 2015 ) membagi perilaku perawatan diri menjadi 2 dimensi yaitu aspek pribadi dan aspek profesional. Dimensi perawatan diri dalam aspek pribadi diidentifikasi berdasarkan kategori umum perilaku perawatan diri termasuk di dalamnya aspek fisik, psikologis, spiritual, sosial, dan rekreasi ( Baker, 2003; O'Halloran \& Linton, 2000; Richards et al, 2010, dalam Dorociak, 2015).

Perawatan diri dalam aspek profesional dikonseptualisasikan berdasarkan tuntutan yang melekat di lapangan dan strategi yang dapat digunakan di tempat kerja untuk memilih bantuan yang tepat dan efektif dalam membangun kesejahteraan. Empat dimensi dalam perawatan diri profesional meliputi keseimbangan psikologis, sosial, keseimbangan kehidupan kerja, dan perkembangan (Coster \& Schwebel, 1997; Elman, Illfelder-Kaye \& Robiner, 2005; Lee \& Miller, 2011; Norcross \& Guy, 2007, dalam Dorociak, 2015 ).

\section{Manfaat Perawatan Diri bagi Konselor}

Layton \& Collins menyatakan bahwa manfaat perawatan diri bagi konselor dalam 4 kategori, yaitu:

a. Manfaat secara fisik, antara lain: bisa istirahat dan relaksasi, penyakit fisik berkurang, merasa direvitalisasi secara fisik, merasa diberi energi kembali, dan merasa lebih seimbang.

b. Manfaat secara mental, antara lain: stres atau kecemasan berkurang, merasa lebih santai, menenangkan pikiran, membiarkan untuk fokus kepada diri sendiri, memahami diri, peristiwa kehidupan dan perasaan, penyegaran mental dan keseimbangan dalam batin, melepaskan sementara pikiran menganalisa, logis, kritis, menghakimi, dan berorientasi pada tujuan, meningkatkan kewaspadaan, mendapat pembelajaran baru (misalnya melalui buku), dan meninjau masa lalu atau masa sekarang untuk mengenali gambaran yang lebih besar serta mendapatkan kejelasan tentang masa depan.

c. Manfaat psiko-spiritual, antara lain: merasakan keheningan batin dan kedamaian, merasakan kepercayaan, keamanan, kekuatan, perlindungan, belas kasihan, toleransi, rasa hormat, kerendahan hati, kebaikan, kesabaran, kesadaran diri, wawasan, perhatian, penerimaan diri / orang lain / kehidupan, peneguhan, motivasi, penyembuhan emosional, pelepasan rasa malu maupun sakit, keseimbangan dan integrasi antara pikiran dan tubuh, perasaan gembira, cinta, kebebasan, kesenangan, dan memahami tujuan dan makna hidup.

d. Kemampuan yang dapat ditingkatkan, antara lain: lebih jelas tentang batasan pribadi atau profesional seseorang, hidup yang lebih selaras, lebih produktif di tempat kerja, dapat mengatasi tekanan dan tuntutan, mengalami rasa puas, lebih mencintai diri sendiri dan orang lain, melihat sesuatu hal secara berbeda dengan lebih jelas dan dengan perspektif 
yang baru, bisa memecahkan masalah pribadi yang lebih kompleks, meningkatkan kreativitas, dan bisa lebih aktif dan produktif dalam hidup.

\section{Bentuk Strategi Perawatan Diri}

Norcross \& Guy (2007) menggambarkan dan mengilustrasikan strategi perawatan diri yang didasarkan pada penelitian dan pengalaman klinis dari penulis, rekomendasi dari ahli terapi, daftar checklist "perawatan diri", dan saran untuk membaca lebih lanjut. Strategi perawatan diri tersebut, antara lain:

a. Membuat agenda kegiatan setiap bulan. Menurut Weiss (2004, dalam Norcross \& Guy, 2007), metode sederhana dan efektif untuk memprioritaskan perawatan diri adalah membuat agenda kegiatan dalam sebuah kalender. Misalnya dalam satu bulan dibuat kegiatan makan siang bersama teman, membuat waktu latihan, atau acara keluarga.

b. Memfokuskan pada hadiah. Ketika menghadapi stres dalam pekerjaan, psikoterapis tetap fokus untuk mencintai pekerjaan tersebut sehingga membantu untuk mengurangi stres dan tetap bisa melanjutkan pekerjaannya karena ada beberapa hal atau hadiah yang bisa didapatkan psikoterapis di dalam pekerjaannya, yaitu 1) menambah anggota keluarga baru, 2) mempunyai ragam pengalaman karena akan menemui berbagai macam karakter seseorang sehingga bisa memperlajari kisah pribadi yang menarik, 3) memiliki kestabilan emosi, hubungan interpersonal misalnya empati, toleransi, dan keahlian dalam menangani masalah keseharian, 4) efektivitas pribadi yang didapatkan ketika membantu klien dalam menghadapi kesedihan atau rasa sakit akibat kehilangan orang yang dicintai, 5) arti hidup yang dipenuhi dengan tujuan dan arti kehidupan dengan pelayanan yang diberikan setiap hari kepada klien, 6) pengakuan publik yang biasanya didapatkan dari keluarga atau teman-teman yang ingin berkonsultasi seolah-olah psikoterapis adalah seorang penyihir yang mengetahui adanya rahasia dalam diri manusia, dan 7) peluang kerja karena psikoterapis yang kompeten banyak dicari di sebagian besar negara untuk pelayanan, untuk mengajar di rumah ibadah, perguruan tinggi, sekolah, rumah sakit, panti jompo, dan lain sebagainya.

c. Mengenali sinyal bahaya yang muncul dari dalam diri. Perawatan diri psikoterapis dimulai dengan mengenali dan mempersiapkan diri dari bahaya yang muncul dari dalam diri dan tidak bisa dihindarkan. Psikoterapis perlu memahami berbagai bentuk bahaya yang muncul sehingga memungkinkan untuk secara lebih efektif dalam mengatasinya.

d. Mengurus tubuh. Beberapa hal singkat namun penting mengenai perawatan tubuh untuk para psikoterapi antara lain: tidur, istirahatkan tubuh, nutrisi dan hdrasi yang cukup, dan olahraga.

e. Memelihara suatu hubungan. Selain memelihara suatu hubungan baik dengan orang lain yang berkaitan dengan pekerjaan, psikoterapis juga perlu untuk memelihara hubungan baik dengan orang-orang di luar ranah pekerjaan mereka, seperti misalnya pasangan, anggota keluarga, teman, mentor pribadi, ataupun psikoterapis pribadi.

f. Menetapkan batas. Hal mendasar yang bisa dijadikan acuan seorang psikoterapis untuk melakukan perawatan diri misalnya dimulai dengan memutuskan berapa jam terapi yang akan dilakukan dalam setiap minggunya, menerima konsultasi dengan klien pada malam hari apabila sudah membuat janji terlebih dahulu, dan berapa banyak istirahat yang diperlukan sepanjang hari untuk memastikan perawatan diri yang berkualitas.

g. Merestrukturisasi kognisi. Restrukturisasi kognitif dimulai dengan kesadaran diri dan pemantauan diri dengan mengenali apa yang dikatakan kepada diri sendiri, baik secara eksplisit maupun implisit. Sebagai seorang psikoterapis, bergembiralah atas keberhasilan yang pernah dilakukan, terima keterbatasan manusiawi yang dimiliki, dan terima diri sendiri tanpa syarat. Pasti ada banyak kasus dimana kehidupan klien menjadi meningkat secara signifikan karena kehadiran dan intervensi dari seorang psikoterapis.

h. Menetapkan pelarian yang sehat. Pelarian sehat yang mungkin dilakukan seorang psikoterapis antara lain: istirahat agar menciptakan lebih banyak waktu dan energi, relaksasi secara berkala, tertawa, mengundang kolega, staf, teman ataupun anggota keluarga untuk berkumpul, ikut dalam kegiatan amal, mempunyai hobi baru hanya untuk bersenang-senang, pergi berlibur ke suatu tempat, menghabiskan waktu dengan buku-buku untuk kesenangan dan hiburan, melakukan apapun misalnya hany bersantai tanpa adanya tuntutan, dan melukis diatas kanvas. 
i. Menciptakan lingkungan yang berkembang. Memperbaiki atau menciptakan lingkungan kerja yang berkembang misalnya menciptakan lingkungan tempat bekerja sebaik mungkin sehingga membuat nyaman bagi psikoterapis dan juga klien, sediakan air dan makanan ringan yang segar untuk dijadikan makanan ketika siang hari, dan ciptakan lingkungan kerja yang aman

j. Menjalani terapi pribadi. Menjalani terapi pribadi apabila diperlukan oleh seorang psikoterapis dengan memilih psikoterapis yang cermat terutama pada kompetensi yang dimiliki, pengalaman klinis, reputasi, dan kehangatan interpersonal.

k. Menumbuhkan spiritualitas. Psikoterapis merasa pekerjaannya adalah tindakan ibadah. Tuhan menunjukkan jalan menjadi seorang psikoterapis untuk membantu meringankan penderitaan manusia dan membawa suatu keutuhan pada klien. Maka dari itu, bukan hal yang aneh apabila psikoterapis menjadi lebih religius selama masa perawatan.

I. Menumbuhkan kreativitas. Rothenberg (1988, dalam Norcross \& Guy, 2007) mengatakan bahwa kreativitas adalah keadaan, kapasitas, dan kondisi untuk melahirkan sesuatu yang baru dan berharga. Contoh kreativitas dalam psikoterapi antara lain: menghargai proses terapi itu sendiri, kesadaran akan paradoks pengobatan (misalnya klien yang untuk sementara tergantung pada terapis untuk maju), menciptakan metafora yang efektif untuk menyampaikan pesan, mengakui kesulitan dalam psikoterapi, dan mengembangkan terapi yang baru dan berhasil.

\section{Simpulan}

Perawatan diri ketika menghadapi stres sangat penting diketahui oleh seorang konselor. Hal ini dikarenakan sebagian besar konselor belum memiliki pengetahuan yang memadai tentang pentingnya mengelola dan mengendalikan stres yang terjadi pada dirinya, sehingga akan mempengaruhi kinerjanya sebagai konselor di sekolah. apabila stres yang dialami tidak diatasi secara benar, akan memiliki dampak negatif yang tidak hanya dirasakan oleh para konselor tetapi juga untuk klien mereka.

Selama ini konselor menganggap permasalahan yang terjadi akan terselesaikan dengan sendirinya, tidak sedikit pula yang mencoba menghindari penyebab stres yang mereka alami. Ketika hal ini dibiarkan, maka dapat mengarah ke berbagai hasil negatif termasuk terganggunya kesehatan fisik dan mental konselor itu sendiri. Ada beberapa cara merawat diri yang dilakukan ketika menghadapi stres, mulai dari berolahraga, berpikiran positif, melakukan relaksasi, hingga membaca buku.

Seorang konselor setidaknya mengetahui gejala stres yang dialaminya sehingga bisa menemukan panduan perawatan diri yang dirasa tepat untuk mengatasi stres yang dialami. Dengan teratasinya stres yang dialami oleh seorang konselor, diharapkan mereka dapat semaksimal mungkin menjalankan tugas dan tanggung jawabnya sebagai seorang konselor di sekolah.

\section{Ucapan Terima Kasih}

Terima kasih kepada semua pihak yang membantu selama penulisan artikel.

\section{Daftar Rujukan}

Agus, M., \& Wahyudi, S. (2017). Peran Ganda Guru Bimbingan dan Konseling di SMP Diponegoro. Komunika, 11(1), 55-72.

Azizah, Ainul., \& Purwoko, Budi. (2017). Studi Kepustakaan Mengenai Landasan Teori dan Praktik Konseling Naratif. Jurnal BK Unesa, Vol. 7, No. 2

Bradley, N., Whisenhunt, J., Adamson, N., \& Kress, V. E. (2013). Creative approachers for promoting counselor self-care. Journal of Creativity in Mental Health, 8 (4), 456-469 
Dorociak, Katherine E., et al. (2017). Development of the Professional Self-Care Scale. Journal of Counseling Psychology, Vol. 64, No. 3, 325-334

Fuad, Miskinul. (2009). Kualitas Pribadi Konselor: Urgensi dan Pengembangannya. Komunika: (Agus \& Wahyudi, 2017)Jurnal Dakwah dan Komunikasi, Vol. 3. No. 2, 247-254

Hartono, Boy Soedarmadji. (2012). Psikologi Konseling. Jakarta: Kencana Predana Media Grup

Norcross, J. C. (2000). Psychotherapist self-care: Practitioner-tested, research-informed strategies. Professional Psychology: Research And Practice, 31(6), 710-713

Norcross, J.C., \& Guy, J. D. J. (2007). Leaving it at the office: A Guide to psychotherapist selfcare. New York: The Guilford Press

Peraturan Menteri Pendidikan dan Kebudayaan Republik Indonesia Nomor 81A tahun 2013 tentang Implementasi Kurikulum 2013

Rumeser, Johannes A. A. , \& Tambuwun, Theodora Elma. (2011). Hubungan Antara Tingkat Stres Kerja dengan Pemilihan Coping Stress Stretegy Karyawan di Kantor Pusat Adira Insurance. Humaniora Vol. 2 No.1 April 2011: 214-227

Stranks, Jeremy. (2005). Stress at Work: Management and Prevention. UK: Elsevier, Ltd

Susanti, Rita., Riswani, \& Nurhasanah, Bakhtiar. (2018). Kejenuhan di Kalangan Guru Bimbingan dan Konseling di SMAN Provinsi Riau.

Sandra, R. (2015). Konsep Stres Kerja Guru Bimbingan dan Konseling. Jurnal EDUCATIO: Jurnal Pendidikan Indonesia, 1(2002), 80-85.

Sugiyono. (2012). Metode Penelitian Kuantitatif Kualitatif dan R\&D Bandung: Alfabeta

Susanti, Rita., Riswani, \& Nurhasanah, Bakhtiar. (2018). Kejenuhan di Kalangan Guru Bimbingan dan Konseling di SMAN Provinsi Riau.

\section{Competing interests:}

The authors declare that they have no significant competing financial, professional or personal interests that might have influenced the performance or presentation of the work described in this manuscript. 